\title{
Implementation of Virtual Laboratory as Media in Elementary School Teacher Education Universitas Pasundan
}

\author{
Devi Rahmiati \\ Elementary School Teachers Education Universitas Pasundan \\ devirahmiati@unpas.ac.id
}

\begin{abstract}
The aim this research to get an overview are the using of Virtual Laboratory as media learning students of Elementary School Teacher Education at Universitas Pasundan. The use of media in learning is very important to make solution for lecturers to applied basic concept of science in elementary school. This research in the fourth semester of the Academic Year 2019/2020 in Class A amounting to 40 people. The research method is quasi-experimental with analysis data used a paired t test with SPSS version 21.0 for windows. Based on data analysis, the results is $t_{\text {hitung }}=2,830>\mathrm{t}_{\text {tabel }}=1,686$, then $\mathrm{H}_{0}$ rejected and $\mathrm{H}_{1}$ accepted. It can be concluded that there are significant the used virtual laboratory media in basic concept of science subject in Elementary School Teacher Education at Universitas Pasundan. Its means there are different knowledge and abilities of students at the pre test and post test result if learning used virtual laboratory as media learning in basic concept of science subject at elementary school. The use of virtual laboratory as a media in the learning process will be able to improve and provide a better meaning of learning outcomes characterized students.
\end{abstract}

Keywords : virtual laboratory media, Elementary School Teacher Education at Unpas, and basic concept of science subject.

\section{Introduction}

In the era of Industrial Revolution 4.0, the government developed a program to improve the quality of learning through Student Centered Learning based on the use of Information and Communication Technology (ICT). Its implementation in the field requires lecturers to carry out a learning process that encourages renewal efforts in the utilization of information and communication technology through a collaborative learning activity system. Through these collaborative activities, the development of learning by lecturers can build students' knowledge by utilizing ICT-based learning media so that learning can take place in a sustainable, communicative, and innovative way.

Schools as formal educational institutions need to prepare students for skilled in meeting the needs as individuals in society for the future. This requirement requires the school to print the learners who are skilled, agile, smart intellectually, emotionally, and socially. There is in Law number 20 of 2003 on National Education System states that the purpose of education is the "development of students' potentials to become a man of 
faith and fear of God Almighty, noble, healthy, knowledgeable, skilled, creative, independent and become citizens of a democratic and responsible " [1].

The ability of 21 st century learners according to Trilling [2] one of which is literacy skills in technology and communication. These demands were answered by the development of various learning activities that came into contact with technology. It is expected that students often interact with technology and not experience technology stuttering, so that later students can create, design and innovate with technology. So as to create these conditions, it takes an atmosphere that involves a digital touch by the teacher in the classroom.

In accordance with Law No. 14 of 2005 on teachers and lecturers clause 10 [3] that one of the competencies teachers must be owned by a teacher is professional competence. Its capabilities include the ability of teachers to support the performance as a teacher starts from the planning of learning, implementing the learning process, and evaluate learning appropriate to the learning objectives. Therefore, should the prospective teacher should be utilizing a variety of media, resources, strategies, and learning methods in order to create meaningful learning [4].

Learning media is one of the important components in the education system that cannot be ignored. During the learning process, learning media has an important role to help lecturers in conveying scientific material concepts that must be understood by students, making it easier for students to understand and apply the concepts presented. The use of media in the learning process is inseparable from the functions and benefits that are felt in order to generate interest, motivation, and stimulation and even bring psychological influence to students in the learning process.

Therefore, a lecturer must be skilled in choosing learning media to help students understand concepts in an optimal, practical, efficient, and can arouse student learning motivation. But actually as a lecturer not only can you use learning media, but also can find, modify, and even make a variety of learning media that are effective, fun, efficient, and in accordance with the characteristics of students to have an impact on improving student learning outcomes. Here is figure virtual lab are used in basic concept of science subject in elementary school:

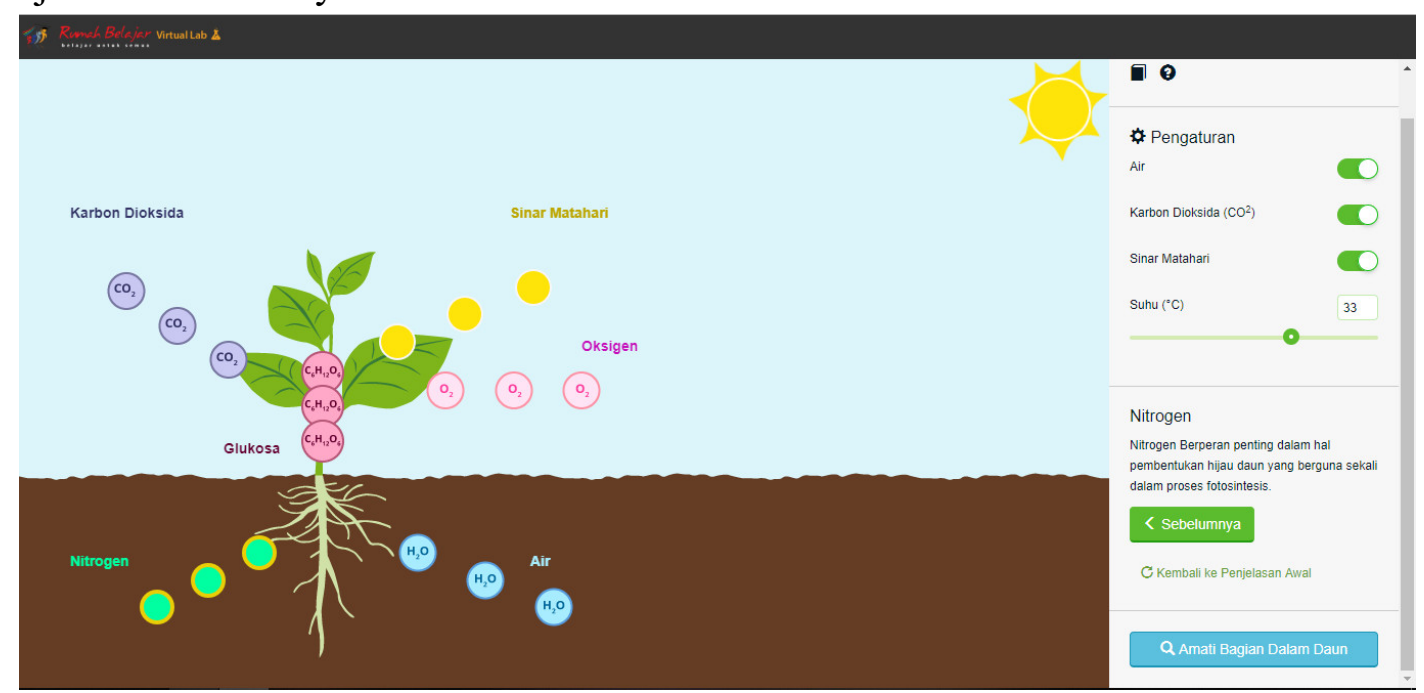

Figure 1. Virtual Laboratory about photosynthesis process [5] 
Good learning media are learning media that can involve the five senses of students to be active in learning activities. While the characteristics of the lecture material Basic Concepts of Science in Elementary School still dominate in the form of a set of concepts, material, and law which presentation of material is often presented in the form of text that is less interesting through power point so that students only listen to the lecturer when delivering the material. This makes students less interested in learning materials, so the learning outcomes become less optimal. Therefore, one way to overcome this problem is to use learning media Virtual laboratory. Virtual laboratory (virtual lab) is one of the superior products as a result of advances in information technology and laboratories in the learning process. Virtual lab based learning is an alternative learning as a substitute for limited facilities and infrastructure owned by an educational institution, namely a laboratory. Virtual laboratories or also called virtual labs are a series of tools, materials, and laboratories in the form of computer software that is operated by a computer or device so that it can carry out continuous simulations in a laboratory.

Virtual laboratory (virtual labs) can develop science process skills. Learning science with simulation allows interaction between students and simulation programs. Where students can modify and manipulate parameters to produce certain consequences shown by the simulation program. So simulations can develop student science process skills, namely skills to manipulate, test, explore, predict, formulate questions, build hypotheses, collect data and observe, analyse, and give meaning to the physical symptoms that occur. The science process can also develop student skills in using scientific methods to better understand patterns of science and nature. Its sample anatomy leaf with microscope:

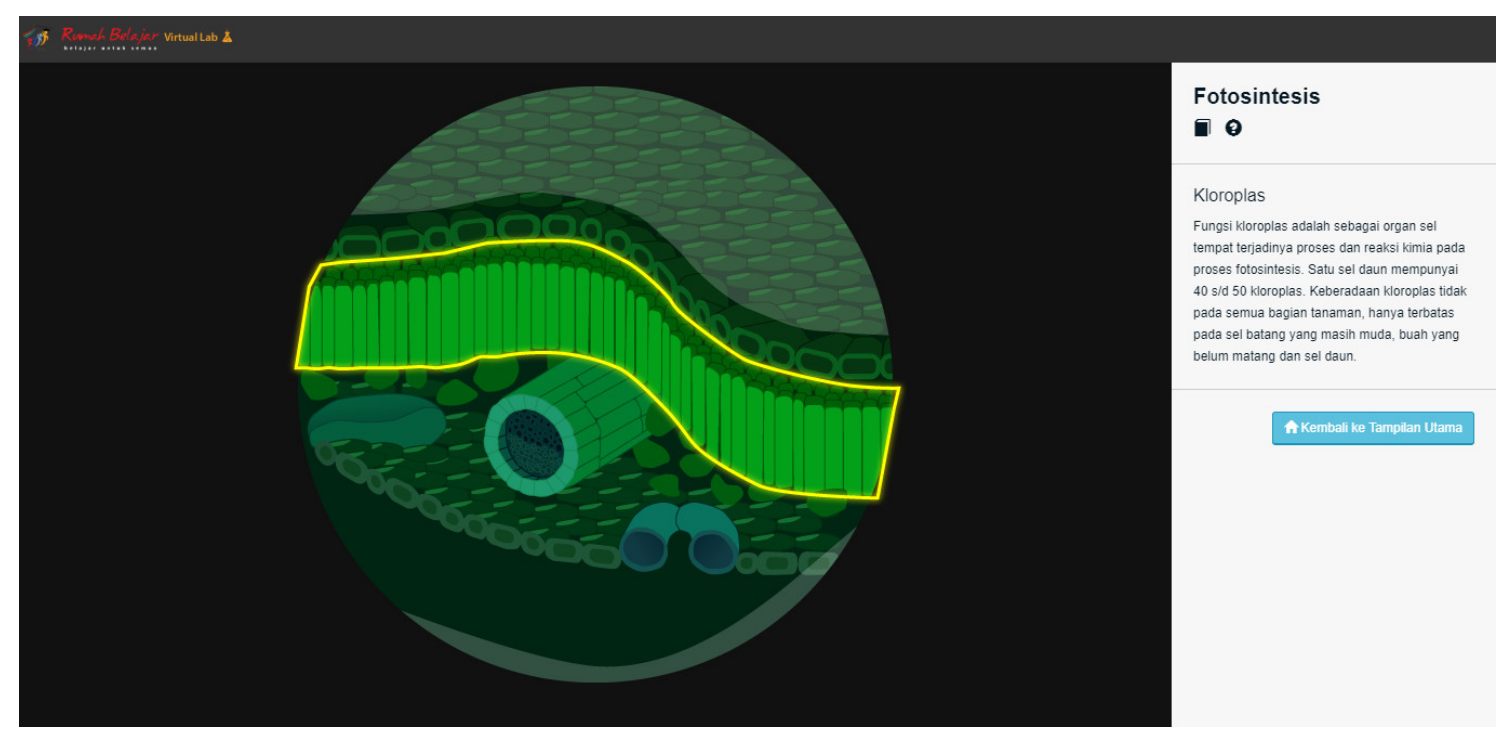

Figure 2. anatomy leaf [5]

In a virtual lab (simulation), students can collect data quickly in any situation, and it is also possible to conduct experiments that are not normally done in the laboratory in 
general. With a virtual lab, students can see changes that occur in a natural phenomenon that may be difficult to see or even have a dangerous risk if done with ordinary observation. The virtual lab learning media (simulation) can increase students' motivation and interest, because problems can be quickly known to them so that they can also quickly get feedback to see the truth of the conclusions. Basically, media in learning activities are used to help study difficult objects presented in the classroom. The use of media in the learning process will be able to provide a better meaning of teaching materials.

\section{Methods}

This research method is a quasi-experimental with design research is a pretest and posttest design group. The population in this study were students PGSD FKIP Unpas at fourth Semester Academic Year 2019/2020 were taking courses in basic concept of science subject in elementary school. Samples were taken using a convenience sampling technique, which means that the subject is determined by the researchers based on the convenience of researchers in conducting research that students PGSD Semester IV Class $\mathrm{A}$ is an amounting to 40 people.

Data collection techniques by a test of mastery concepts, observation, and documentation. Mechanical testing data was analyzed by using paired $t$ test with SPSS version 21.0 for windows [6]. This test aims to see improve in the value of pretest and posttest of students in class A at basic concept of science subject in elementary school.

\section{Results and Discussion}

\subsection{Result}

In this reserach, data processing in the form of quantitative data to test the hypothesis by using paired t test. Pretest and posttest results data is processed using SPSS version 21.0 for windows. The next test is the mean similarity test with t test in count SPSS version 21.0 for windows. The hypothesis formulated in the form of statistical hypothesis (one side test) [7], as follows:

$$
\begin{aligned}
& \mathrm{H}_{0}: \mu 1=\mu 2 \\
& \mathrm{H}_{1}: \mu 1 \neq \mu 2
\end{aligned}
$$

Information:

$\mathrm{H}_{0}$ : No different significant knowledge and abilities of students at the pre test and post test result in basic concept of science subject at elementary school

$\mathrm{H}_{1}$ : There are different significant knowledge and abilities of students at the pre test and post test result in basic concept of science subject at elementary school

The t-test results shown in Table 1. 
Table 1. Output Test-t Paired Samples Test

\begin{tabular}{|c|c|c|c|c|c|c|c|c|c|c|}
\hline & & \multicolumn{4}{|c|}{$\begin{array}{c}\text { Levene's Test } \\
\text { for Equality of } \\
\text { Variances }\end{array}$} & \multicolumn{3}{|c|}{ t-test for Equality of Means } & & \\
\hline & & \multirow[b]{2}{*}{$\mathrm{F}$} & \multirow[b]{2}{*}{ Sig. } & \multirow[b]{2}{*}{$\mathrm{T}$} & \multirow[b]{2}{*}{ Df } & \multirow{2}{*}{$\begin{array}{l}\text { Sig. } \\
(2- \\
\text { tailed })\end{array}$} & \multirow{2}{*}{$\begin{array}{c}\text { Mean } \\
\text { Difference }\end{array}$} & \multirow{2}{*}{$\begin{array}{l}\text { Std. Error } \\
\text { Difference }\end{array}$} & \multicolumn{2}{|c|}{$\begin{array}{l}95 \% \text { Confidence } \\
\text { Interval of the } \\
\text { Difference }\end{array}$} \\
\hline & & & & & & & & & Lower & Upper \\
\hline Pair 1 & Pretest - Posttest & ,977 & 329 & 2,830 & 38 &, 007 & ,13900 & ,04912 & 23843 & 03957 \\
\hline
\end{tabular}

Based on the calculations, then $t_{\text {hitung }}$ is 2,830 . While at the $5 \%$ significance level $(0.05), t_{1-\alpha}\left(\mathrm{n}_{1}+\mathrm{n}_{2}-2\right)$ yaitu $\mathrm{t}_{\text {tabel }}(38)=1,686$. By looking at the results $\mathrm{t}_{\text {hitung }}$ and $\mathrm{t}_{\text {tabel }}$ it is seen that $\mathrm{t}_{\text {hitung }}=2,830>\mathrm{t}_{\text {tabel }}=1,686$, then $H_{0}$ rejected and $\mathrm{H}_{1}$ accepted. Thus it can be concluded that there are significant the used virtual laboratory learning media in basic concept of science subject at elementary school.

\subsection{Discussion}

Some things that will be discussed include learning outcomes in the form of mastery concepts, the influence of used virtual laboratory as learning media, and basic concept of science subject in elementary school.

\subsubsection{Learning outcomes}

Based on the analysis, it can be concluded that this research declared successful seen have a significant the used virtual laboratory learning media in basic concept of science subject at elementary school. This is consistent with previous research that the application virtual laboratory as a media to improve learning outcomes characterized in class A. Results of study here is closely connected with the mastery concept which is measured through an evaluation of the pretest and posttest.

Learning outcomes or behavioral changes that give rise to abilities can be in the form of the main results of teaching (instructional effects) as well as by-products (nurturant effect) in Purwanto [8]. The main results of teaching in this case learning is the ability of learning outcomes that are planned to be realized in the curriculum and learning objectives. While the results of accompaniment are learning outcomes achieved but not planned to be achieved.

The mastery of concepts derived from the learning process, while learning is a cognitive process that involves three processes are almost same time acquire new information, and transformation of information, and to test the relevance of knowledge. Someone said to master of concept if the person understood the concepts learned based on the characteristics possessed by the object so as to explain using their own words according to their knowledge. [9]

From the above explanation can be concluded that virtual laboratory learning media used in this research can affect student learning outcomes significantly visible from the correlation test, particularly on the matter in the basic concept of science subject in elementary school. 


\subsubsection{Virtual Laboratory as media learning}

Clark, et.al. in Margaret describes a simulation with a broader definition, where simulations are computational modeling of natural phenomena, or real (real) situations and event hypotheses, which allow users to explore in manipulating or modifying parameters in it. This definition explains the interaction between simulation programs and students or users of simulation programs. Where the interaction in question is the opportunity for students to manipulate or modify the parameters or simulations in a little to see the effects or consequences of changing these parameters or variables on other variables and the overall simulation phenomenon. Plass, Homer, and Hayward in Margaret reveal that simulation media is different from static images such as graphs or diagrams in books, because simulations are dynamic but simulations differ from ordinary dynamic images such as animation because in simulations it allows users to be able to interact. Simulation allows users to observe and interact by modeling a process that might be abstract. This makes the simulation profitable to understand and predict a phenomenon, such as electricity. [10]

Based on some of the definitions above, it can be concluded that simulation media is a representation or modeling of objects, systems and real phenomena or imagination, and users can interact with these models. Learning by modeling using computer simulation is one of the solutions or alternatives offered to support science learning. Virtual media is a learning media in which the material used for learning activities is a complete set of computers with software specifically designed for practical activities. This software contains animations of material tools and design of learning activities. So that students just run a simulation of learning activities in accordance with the material variables provided and vary them to see the dependent variable that will appear or occur.

\section{Conclusion}

Based on the results of data analysis and hypothesis research, it can be concluded that there are significant learning used virtual laboratory media in through a learning process that involves at basic concept of science subject at elementary school in society.

\section{Acknowledgements}

This work was supported by Faculty of Teacher Training and Education Universitas Pasundan.

\section{References}

[1] Kemdikbud. (2003). Law number 20 of 2003 on National Education System. Jakarta: Kemdikbud.

[2] National Education Association. (2014). Preparing 21st Century Students for a Global Society: An Educator' 's Guide to the “Four Cs ." Los Angeles: NEA.

[3] Kemdikbud. (2005). Law No. 14 of 2005 on teachers and lecturers clause 10. Jakarta: Kemdikbud. 
[4] Sanjaya, Wina. (2006). Strategi Pembelajaran Berorientasi Standar Proses Pendidikan. Jakarta: Prenadamedia Group. Hlm 61.

[5] https://belajar.kemdikbud.go.id diakses 05 Januari 2019.

[6] Sugiyono. (2013). Metode Penelitian Administrasi. Bandung: Alfabeta. Hlm 271.

[7] Arikunto. (2009). Dasar-Dasar Evaluasi Pendidikan. (Edisi revisi). Jakarta: Bumi Aksara. Hlm 29.

[8] Purwanto. (2009). Panduan Pengembangan Model Pembelajaran IPA Terpadu. Jakarta: Depdiknas.

[9] Pradina, R.A. (2010). Penguasaan Konsep Sistem Reproduksi dengan Pembelajaran Aktif Menggunakan Kartu Sortir. Bandung: Skripsi UPI: Tidak diterbitkan. Hlm 11.

[10] Margaret, A.H., \& Margaret, H. (2011). Learning Science Through Computer Games and Simulations. Tersedia di http://www.nap.edu/catalog/13078.html. Diakses pada 7 Februari 2014. p. 1-3. 